\title{
Solubilization of Phenols and Sugars from Raspberry Extrudate by Hydrothermal Treatments
}

\author{
Juan Cubero-Cardoso ${ }^{1}{ }^{(0)}$, Ángeles Trujillo-Reyes ${ }^{1}{ }^{\mathbb{C}}$, Patricia Marín-Ayllón ${ }^{1}$, \\ Guillermo Rodríguez-Gutiérrez ${ }^{1}$, Denys Villa-Gomez ${ }^{2} \mathbb{D}$, Antonio Serrano ${ }^{1,2} \mathbb{D}$, Rafael Borja ${ }^{1} \mathbb{D}$ \\ and Fernando G. Fermoso ${ }^{1, * \mathbb{D}}$ \\ 1 Instituto de Grasa, Spanish National Research Council (CSIC), Ctra. de Utrera, km. 1, 41089 Seville, Spain; \\ juan.cubero@ig.csic.es (J.C.-C.); atrujillo@ig.csic.es (Á.T.-R.); paramayl@gmail.com (P.M.-A.); \\ guirogu@ig.csic.es (G.R.-G.); antonio.serrano@ig.csic.es (A.S.); rborja@cica.es (R.B.) \\ 2 School of Civil Engineering, Campus St. Lucia-AEB Ed 49, The University of Queensland, \\ St Lucia 4067, QLD, Australia; d.villagomez@uq.edu.au \\ * Correspondence: fgfermoso@ig.csic.es; Tel.: +34-9-5461-1550
}

Received: 26 June 2020; Accepted: 13 July 2020; Published: 15 July 2020

\begin{abstract}
Raspberry extrudate residue has bioactive compounds in its matrix that are considered high-added value compounds. In the present study, different hydrothermal treatments were carried out using different operational systems, temperatures and times to solubilize raspberry extrudate in order to obtain these bioactive compounds (i.e., sugars and phenolic compounds). Hydrothermal treatment conditions were assessed in the range of $60{ }^{\circ} \mathrm{C}$ to $210{ }^{\circ} \mathrm{C}$, with increments of $30{ }^{\circ} \mathrm{C}$. The hydrothermal treatment at $210^{\circ} \mathrm{C}$ for 5 min with direct steam and decompression was the most efficient process based on the solubilization of sugars and phenols, as well as on the antioxidant capacity of the products recovered in the liquid phase after treatment. Under these conditions, the concentration of soluble phenols was more than double the concentration in the raw raspberry extrudate, with more than $5000 \mathrm{mg}$ phenols per kilogram of raspberry extrudate. The obtained values demonstrate the potential of applying this treatment for recovering valuable bioactive compounds from raspberry extrudate.
\end{abstract}

Keywords: raspberry extrudate; hydrothermal treatments; antioxidant compounds; phenolic compounds

\section{Introduction}

Up to 870,000 tons of raspberries are produced worldwide every year. In Spain, more than 43,000 tons of raspberries were produced in 2018 [1]. Several components of raspberries have been found to provide potential health benefits, including cardiovascular, antihypertensive, antioxidant, antiproliferative, and antidiabetic effects [2,3]. These health effects are due to the synergistic combination of nutrients, minor compounds, and fibres that come from raspberries, which suggests the raspberry could be considered as a functional food [4].

Raspberries are an important source of bioactive compounds such as vitamin C, riboflavin, folic acid, niacin, magnesium, potassium, copper, and iron [2]. The high antioxidant capacity of raspberries is related to the presence of major groups of bioactive compounds such as ellagitannins and anthocyanins, while phenolic acids and flavonoids are the minor phenolic constituents [5]. In addition to their antioxidant capacity, anthocyanins are also responsible for the characteristic red color of the raspberry [6]. The main anthocyanins contained in raspberries are derived from cyanidins in non-acylated forms [7]. Among the ellagitannins, ellagic acid, as well as the anthocyanins, are of high interest due to their possible chemopreventive effects $[8,9]$. Raspberries also contain a high amount of 
sugars and fibres, which are combined to form lignocellulose. Lignocellulose primarily contains lignin, hemicellulose, and cellulose, which are composed of sugars and acid sugars [10]. Pectins, which are composed of acid sugars, have been associated with important health benefits, i.e., preventing diabetes and cardiovascular diseases [11].

Besides the production and marketing of raspberries as fresh fruit, this sector includes the manufacture of derived products such as juices, jams, etc. These products are generally manufactured from a raspberry concentrate, which is industrially obtained by sieving raspberries several times with different mesh size $(1.5$ and $0.5 \mathrm{~mm})$. During the process, the sieves retain a residual fraction, called residual raspberry extrudate (RE), which is composed of the fibres and achenes that contain most of the bioactive compounds found in raspberry fruit [12]. The achenes contain a wide variety of phenolic compounds with a high antioxidant capacity whereas the fibres are rich in other phenolic compounds [13-15].

Because RE is a by-product that contains bioactive compounds, its high added-value compounds such as phenols, sugars should be valorised instead of wasted. The product market for these compounds has already been envisaged, for example, phenolic compounds can be are used as additives in foods to prevent oxidation [16], sugars can be used in fermentation and biorefinery processes [17-19], and pectins can be used as gelling or thickening agents [20].

As reported for other food industry wastes [21-23], hydrothermal treatments are one option for solubilizing and separating the raspberry extrudate into a solid and a liquid phase with high added-value compounds; however, optimal conditions for the thermal pre-treatment, as well as the recovery efficiencies that may be achieved, need to be determined.

Hydrothermal treatments at low temperatures (less than $150^{\circ} \mathrm{C}$ ) mainly induce the deflocculation of macromolecules with minimum solubilization of lignocellulosic matter [24]. Hydrothermal treatments at medium temperatures (around $150-180^{\circ} \mathrm{C}$ ) mostly affect hemicelluloses, and shortly thereafter, cellulose and lignin [25]. In severe hydrothermal treatments at high temperatures (more than $180{ }^{\circ} \mathrm{C}$ ) and pressure conditions with rapid decompression, the cellulose and lignin are more affected than during treatments at medium temperatures. At the same time, treatments at high temperatures can convert part of the hemicellulose into smaller sugars, which can form undesirable compounds such as hydroxymethylfurfural (HMF), or they can enhance the formation of bioactive structures like phenolic glycosides or antioxidant soluble and insoluble fibres [21,26].

The main objective of this work was to evaluate the hydrothermal treatment using a wide range of temperatures $\left(60-210{ }^{\circ} \mathrm{C}\right)$, to find the optimal conditions for the recovery of high added-value compounds such as phenols from raspberry extrudate.

\section{Materials and Methods}

\subsection{Raspberry Extrudate}

Raspberry extrudate is obtained from raspberry fruit, by using a twin-screw extruder with a $0.5 \mathrm{~mm}$ mesh and applying a heat treatment for enzymatic inactivation at $65^{\circ} \mathrm{C}$. Raspberry extrudate was collected in the HUDISA S.A factory, (Huelva, Spain) in 2018. After collection, it was immediately stored at $-20^{\circ} \mathrm{C}$ to prevent any possible fermentation or degradation.

\subsection{Hydrothermal Treatments}

Six hydrothermal treatments were carried out with increases in the temperature of thirty degrees. These hydrothermal treatments were classified into three temperatures ranges: low $\left(60{ }^{\circ} \mathrm{C}, 90{ }^{\circ} \mathrm{C}\right.$, and $120^{\circ} \mathrm{C}$ ), medium $\left(150^{\circ} \mathrm{C}\right.$ and $180^{\circ} \mathrm{C}$ ), and high (steam explosion, $210^{\circ} \mathrm{C}$ and $16 \mathrm{~kg} / \mathrm{cm}^{2}$ ).

Low-temperature hydrothermal treatments $\left(60^{\circ} \mathrm{C}, 90^{\circ} \mathrm{C}\right.$, and $\left.120^{\circ} \mathrm{C}\right)$ were carried out by indirect heating at 60 and $90^{\circ} \mathrm{C}$ in a laboratory stove (J.P. Selecta), and at $120^{\circ} \mathrm{C}$ in an autoclave (Trade Raypa Steam Sterilizer). For the low-temperature hydrothermal treatments, $0.35 \mathrm{~kg}$ of raspberry extrudate 
with $0.65 \mathrm{~L}$ of distilled water was added in a Pyrex bottle. The treated RE was centrifuged (Pacisa, Milan, Italy) at $7155 \times g$ to obtain two phases: a solid phase (SP) and a liquid phase (LP).

Medium-temperature hydrothermal treatments $\left(150^{\circ} \mathrm{C}\right.$ and $\left.180^{\circ} \mathrm{C}\right)$ were carried out with steam in a reactor of $100 \mathrm{~L}$ volume, which allow temperatures up to $190^{\circ} \mathrm{C}$ to be obtained and a maximum pressure of 1.2 MPa. The raspberry extrudate was heated by direct steam injection, and indirectly by a heating jacket. Raspberry extrudate samples were processed at $150{ }^{\circ} \mathrm{C}(12.59 \mathrm{~kg})$ and $180{ }^{\circ} \mathrm{C}(6 \mathrm{~kg})$ in the reactor for $60 \mathrm{~min}$.

Steam explosion treatment was carried out in a reactor at pilot-scale (Nusim, S.A., Madrid, Spain). The reactor was equipped with a stainless-steel deposit of $2 \mathrm{~L}$ of volume. The steam explosion reactor was filled with $250 \mathrm{~g}$ of raspberry extrudate, which was directly heated at a temperature of $210{ }^{\circ} \mathrm{C}$ with high-pressure saturated steam at $16 \mathrm{~kg} / \mathrm{cm}^{2}$ for a $5 \mathrm{~min}$ period. After the reaction time, an explosive decompression occurred from $2 \mathrm{~L}$ of reactor chamber up to $120 \mathrm{~L}$ of the expansion deposit. An automatic computing device monitored the time and the temperature in a pre-programmed manner. A centrifuge Pacisa 4226, Milan, Italy at $7155 \times \mathrm{g} / 8000 \mathrm{rpm}$ was used after the medium temperature and steam explosion treatments to separate the SP and LP [27].

\subsection{Extraction of Water-Soluble Compounds}

After the hydrothermal treatments, each LP was centrifuged again to eliminate solids in suspension and microfiltered with $0.45 \mu \mathrm{m}$ nylon microfilters. Then, a method that is extensively used for the analysis of compost samples and based on water extraction [28] was used to determine the amount of the soluble compounds in the RE and each SP. Distilled ( $160 \mathrm{~g})$ water was added to $20 \mathrm{~g}$ of solid phase. After stirring for $24 \mathrm{~h}$ at room temperature, the mixture was centrifuged and microfiltered with the above-mentioned microfilters.

\subsection{Analytical Methods}

The determination of the $\mathrm{pH}$, total solids (TS), mineral solids (MS), volatile solids (VS) chemical oxygen demand (COD), and soluble COD (sCOD) to characterize both phases was performed according to the guidelines of the Standard Methods of APHA [29]. Water-soluble sugars were analyzed by the Anthrone photometric method [30] and water-soluble acid sugars were determined by the m-hydroxydiphenyl method [31] using a spectrophotometer (BIO- RAD iMark Microplate Reader, California, USA). Water-soluble individual sugars were analyzed with and without initial TFA hydrolysis prior to reduction, acetylation, and analysis by gas chromatography (GC), using the method reported by Lama-Muñoz et al. [32]. The detection of HMF was accomplished by high-performance liquid chromatography (HPLC) as recently reported by Rodríguez-Gutiérrez et al. [21]. In order to extract phenolic compounds, $20 \mathrm{~mL}$ of methanol-water $(\mathrm{v} / \mathrm{v}, 80 / 20)$ were added to $10 \mathrm{~g}$ of each solid and liquid phase and incubated for $1 \mathrm{~h}$ at $70{ }^{\circ} \mathrm{C}$ in a water bath. Then, it was microfiltered with $0.45 \mu \mathrm{m}$ nylon microfilters. The phenol concentration was analyzed by the Folin-Ciocalteu spectrophotometric method [33]. All the measurements were carried out at least in triplicate. The mean and standard deviation values were calculated for statistical analysis.

\subsection{Individual Phenols}

Individual phenolic compounds of the soluble RE and liquid phases obtained after the application of the hydrothermal treatments were analyzed following the method proposed by Gil et al. [34] and slightly amended by Pérez et al. [35]. Briefly, quantification of the phenolic compounds was performed in a Beckman Coulter high-performance liquid chromatography (HPLC) system equipped with a System Gold 168 detector, a solvent module 126 and a stainless steel Merck Superspher RP-18 $(250 \times 4 \mathrm{~mm})$ column using acidified water $(2.5 \%$ formic acid) (Solvent $\mathrm{A})$ and acidified methanol $(2.5 \%$ formic acid) (Solvent B) as mobile phases. The detection was performed at 280, 350 and $510 \mathrm{~nm}$, and the sample injection loop was $20 \mu \mathrm{L}$. The purification of the phenolics was carried out by a chromatographic 
system under patent [27] using water as an eluent in the first step and ethanol/water $(20: 80 \mathrm{v} / \mathrm{v})$ in the second step.

\subsection{Antioxidant Determination}

The antioxidant capacity was determined using two different methods, as previously described by Rodríguez et al. [36]. Reducing power $\left(\mathrm{FeCl}_{3}\right)$ and antiradical activity (DPPH) were used to determine the reduction and scavenging capacity the free radicals, respectively.

\subsection{Achenes}

In order to quantify and characterise the achenes contained in RE and in each solid phase obtained after each hydrothermal treatment, $10 \mathrm{~g}$ of sample was taken and dried for $24 \mathrm{~h}$ in a laboratory oven. Then, the achenes were manually separated from the rest of the material and weighed.

\section{Results and Discussion}

\subsection{Mass Distribution after Hydrothermal Treatments and Separation of Phases by Centrifugation}

Table 1 shows the values for the RE mass after each hydrothermal treatment, the mass of the different obtained SP and LP after separation by centrifugation, the mass distribution between phases, and the volume of water added during each hydrothermal treatment.

Table 1. General data about the mass distribution after each hydrothermal treatment.

\begin{tabular}{|c|c|c|c|c|c|c|c|}
\hline $\begin{array}{c}\text { Temperature } \\
\left({ }^{\circ} \mathrm{C}\right)\end{array}$ & $\begin{array}{l}\text { Time } \\
(\min )\end{array}$ & $\begin{array}{l}\text { Pressure } \\
\left(\mathrm{kg} / \mathrm{cm}^{2}\right)\end{array}$ & $\begin{array}{c}\text { Initial RE } \\
\text { Weight (kg) }\end{array}$ & $\begin{array}{l}\text { Incorporated } \\
\text { Water (kg) }\end{array}$ & Phases & $\begin{array}{l}\text { Weight of } \\
\text { Phases (kg) }\end{array}$ & $\begin{array}{c}\text { Mass } \\
\text { Distribution } \\
(\%)\end{array}$ \\
\hline \multirow{2}{*}{60} & \multirow{2}{*}{60} & \multirow{2}{*}{1.00} & \multirow{2}{*}{0.35} & \multirow{2}{*}{0.650} & SP & 0.28 & 29 \\
\hline & & & & & LP & 0.68 & 71 \\
\hline \multirow{2}{*}{90} & \multirow{2}{*}{60} & \multirow{2}{*}{1.00} & \multirow{2}{*}{0.35} & \multirow{2}{*}{0.650} & $\mathrm{SP}$ & 0.31 & 34 \\
\hline & & & & & LP & 0.60 & 66 \\
\hline \multirow{2}{*}{120} & \multirow{2}{*}{60} & \multirow{2}{*}{1.20} & \multirow{2}{*}{0.35} & \multirow{2}{*}{0.650} & $\mathrm{SP}$ & 0.31 & 34 \\
\hline & & & & & LP & 0.59 & 66 \\
\hline \multirow{2}{*}{150} & \multirow{2}{*}{60} & \multirow{2}{*}{5.00} & \multirow{2}{*}{12.59} & \multirow{2}{*}{36.90} & $\mathrm{SP}$ & 4.72 & 10 \\
\hline & & & & & LP & 44.77 & 90 \\
\hline \multirow{2}{*}{180} & \multirow{2}{*}{60} & \multirow{2}{*}{9.00} & \multirow{2}{*}{6.00} & \multirow{2}{*}{7.14} & SP & 2.47 & 19 \\
\hline & & & & & LP & 10.67 & 81 \\
\hline \multirow{2}{*}{210} & \multirow{2}{*}{5} & \multirow{2}{*}{16.00} & \multirow{2}{*}{0.25} & \multirow{2}{*}{2.19} & SP & 0.34 & 14 \\
\hline & & & & & LP & 2.10 & 86 \\
\hline
\end{tabular}

The volume of incorporated water depended on the hydrothermal treatment and on the characteristics of the reactor used in each case. For temperatures below $120^{\circ} \mathrm{C}, 0.65 \mathrm{~kg}$ of water was incorporated. For temperatures above $120{ }^{\circ} \mathrm{C}$ the volume of water incorporated varied due to the need to keep a constant temperature inside the reactor during the hydrothermal treatment (Table 1). Ratios between initial RE weight and incorporated water at temperatures equal and above $120^{\circ} \mathrm{C}$ were: 1:1.86 at $120{ }^{\circ} \mathrm{C}, 1: 2.93$ at $150{ }^{\circ} \mathrm{C}, 1: 1.19$ at $180{ }^{\circ} \mathrm{C}$ and $1: 8.76$ in weight at $210{ }^{\circ} \mathrm{C}$. According to these ratio values, a higher amount of water was introduced in the treatment at $210{ }^{\circ} \mathrm{C}$ compared to the other hydrothermal treatments, even though the hydrothermal treatment at $210^{\circ} \mathrm{C}$ only lasted 5 min, and not $60 \mathrm{~min}$ as occurred with all other hydrothermal treatments. After the hydrothermal treatment and separation of phases by centrifugation, in all cases, most of the mass moved to the LP (Table 1). However, the separation was more effective for the phases obtained at temperatures higher than $120^{\circ} \mathrm{C}$, where the mass percentage of the LP varied from $81 \%$ to $90 \%$. On the contrary, LP obtained from hydrothermal treatments with temperatures below $120^{\circ} \mathrm{C}$ had lower mass percentages, with values around $70 \%$ (Table 1 ). This difference in the mass distribution may be related to the severity of each hydrothermal treatment, which affects the RE cell wall structures to a different degree, allowing a higher or lower degree of solubilization. In fact, it has been reported that hydrothermal treatments at 
temperatures higher than $150^{\circ} \mathrm{C}$ can affect lignocellulosic structures, mainly the hemicellulose, and to a lesser extent, the cellulose [25]. On the other hand, Serrano et al. [37] reported that hydrothermal treatments at $65{ }^{\circ} \mathrm{C}$ for $1 \mathrm{~h}$ had a deflocculating effect on olive mill solid waste, rather than the breakdown of the lignocellulosic fibres.

\subsection{Characterization of the Untreated Raspberry Extrudate and the Solid and Liquid Phases Obtained after Each Hydrothermal Treatment}

The physicochemical characteristics of untreated RE and the different phases obtained for each hydrothermal treatment after separation by centrifugation are shown in Table 2. After the hydrothermal treatment, the $\mathrm{pH}$ values of each phase slightly increased with respect to the untreated RE, although all the phases presented an acid $\mathrm{pH}$, i.e., lower than 5 . The increase in $\mathrm{pH}$ values may be caused by the incorporation of water during direct heating (Table 2). This addition of water, as well as the ability of the cell material to keep water [21], increased the moisture in the substrates after each hydrothermal treatment. The highest moisture content in the SP was achieved after the steam explosion treatment $\left(210{ }^{\circ} \mathrm{C}, 5 \mathrm{~min}, 16 \mathrm{~kg} / \mathrm{cm}^{2}\right)$, probably due to the high proportion of water added with respect to the initial substrate, i.e., $8.76 \mathrm{~L}$ of water per $\mathrm{kg}$ of $\mathrm{RE}$, which was several times higher than the water added in the other hydrothermal treatments (Table 1).

In all hydrothermal treatments, it was observed that around $98 \%$ of the TS were VS, and the highest amount of VS was retained in the SP, i.e., only about $15 \%$ of VS remained in the LP (Table 2). With regard to the organic matter, the measured sCOD/COD ratio indicated that the greatest part of the organic matter was not initially in soluble form, i.e., the sCOD/COD ratio in the untreated RE was 0.09 (Table 2). After the hydrothermal treatments, the solubilization of part of the organic matter resulted in an increase in the SCOD/COD ratio in the sum of SP and LP with values up to approximately 0.13 (Table 2). Although these ratios indicate a difference of around $44 \%$ in respect to the untreated RE, most of the COD was not susceptible to being solubilized and remained in a non-soluble form (Table 2). With regard to the distribution of the soluble organic matter in the phases obtained after the thermal treatments, the values of the sCOD/COD ratio in the SP ranged from 0.01 to 0.06 , indicating that most of the soluble organic matter was moved to the LP, where the sCOD/COD ratio values were higher than 0.90 in all cases (Table 2).

The organic matter contained in different phases obtained after the hydrothermal treatment, contains high added-value compounds that can be recovered with these treatments as well as other organic compounds that could extracted by other techniques such as anaerobic digestion, as was recently proposed by Trujillo-Reyes et al. [38]. 
Table 2. Physicochemical characterization of untreated raspberry extrudate and different solid and liquid phases obtained by centrifugation after all hydrothermal treatments were carried out: untreated raspberry extrudate (RE), solid phase (SP), liquid phase (LP), chemical oxygen demand (COD), soluble COD (sCOD), total solids (TS), mineral solids (MS), volatile solids (VS) and moisture (Moist.).

\begin{tabular}{|c|c|c|c|c|c|c|c|c|c|c|}
\hline Treatment & Phase & $\mathrm{pH}$ & $\begin{array}{c}\text { TS } \\
\text { (mg/kg RE) }\end{array}$ & $\begin{array}{c}\text { MS } \\
\text { (mg/kg RE) }\end{array}$ & $\begin{array}{c}\text { VS } \\
\text { (mg/kg RE) }\end{array}$ & \%Moist. & $\begin{array}{c}\text { COD } \\
\text { (mg/kg RE) }\end{array}$ & $\begin{array}{c}\mathrm{sCOD} \mathrm{COD} \\
(\mathrm{mg} / \mathrm{kg} R E)\end{array}$ & $\begin{array}{c}\mathrm{s} C O D / C O D \\
\text { ratio }\end{array}$ & $\begin{array}{c}{ }_{\mathrm{s} C O D} / \mathrm{COD} \\
\text { Ratio of SP + LP }\end{array}$ \\
\hline RE & & $3.3 \pm 0.1$ & $232,798 \pm 3921$ & $4012 \pm 34$ & $228,786 \pm 3955$ & $76.7 \pm 1.3$ & $328,097 \pm 918$ & $29,640 \pm 585$ & 0.09 & 0.09 \\
\hline \multirow{2}{*}{$60^{\circ} \mathrm{C}, 60 \mathrm{~min}$} & $\mathrm{SP}$ & $3.8 \pm 0.1$ & $147,388 \pm 5041$ & $2274 \pm 237$ & $145,223 \pm 4836$ & $81.4 \pm 2.8$ & $235,793 \pm 4598$ & $11,006 \pm 193$ & 0.05 & \multirow[b]{2}{*}{0.14} \\
\hline & LP & $3.4 \pm 0.1$ & $23,964 \pm 971$ & $223 \pm 49$ & $23,741 \pm 1.021$ & $98.8 \pm 4.0$ & $26,609 \pm 708$ & $25,451 \pm 450$ & 0.96 & \\
\hline \multirow{2}{*}{$90^{\circ} \mathrm{C}, 60 \mathrm{~min}$} & SP & $4.0 \pm 0.1$ & $233,531 \pm 6936$ & $3393 \pm 455$ & $230,138 \pm 6582$ & $73.3 \pm 2.2$ & $286,948 \pm 10,904$ & $15,822 \pm 328$ & 0.06 & \multirow{2}{*}{0.13} \\
\hline & LP & $3.5 \pm 0.1$ & $23,863 \pm 351$ & $627 \pm 410$ & $23,236 \pm 60$ & $98.6 \pm 1.4$ & $28,762 \pm 446$ & $26,146 \pm 115$ & 0.91 & \\
\hline \multirow{2}{*}{$120^{\circ} \mathrm{C}, 60 \mathrm{~min}$} & SP & $3.9 \pm 0.1$ & $180,313 \pm 5536$ & $2085 \pm 83$ & $178,228 \pm 5614$ & $79.3 \pm 2.4$ & $294,066 \pm 8851$ & $15,010 \pm 572$ & 0.05 & \multirow{2}{*}{0.15} \\
\hline & LP & $3.3 \pm 0.1$ & $29,019 \pm 1297$ & $986 \pm 202$ & $28,033 \pm 1099$ & $98.3 \pm 4.4$ & $34,546 \pm 1112$ & $33,191 \pm 684$ & 0.96 & \\
\hline \multirow{2}{*}{$150{ }^{\circ} \mathrm{C}, 60 \mathrm{~min}$} & $\mathrm{SP}$ & $4.6 \pm 0.1$ & $182,312 \pm 3519$ & $1876 \pm 97$ & $180,436 \pm 3555$ & $51.4 \pm 1.0$ & $230,917 \pm 7066$ & $2896 \pm 125$ & 0.01 & \multirow{2}{*}{0.14} \\
\hline & LP & $3.5 \pm 0.1$ & $32,088 \pm 247$ & $1396 \pm 341$ & $30,692 \pm 95$ & $99.1 \pm 0.8$ & $36,996 \pm 518$ & $34,645 \pm 364$ & 0.94 & \\
\hline \multirow{2}{*}{$180^{\circ} \mathrm{C}, 60 \mathrm{~min}$} & SP & $3.9 \pm 0.1$ & $157,138 \pm 534$ & $1136 \pm 16$ & $156,002 \pm 515$ & $61.8 \pm 0.2$ & $216,745 \pm 7694$ & $7612 \pm 109$ & 0.04 & \multirow{2}{*}{0.11} \\
\hline & LP & $3.4 \pm 0.1$ & $36,891 \pm 92$ & $2349 \pm 145$ & $34,542 \pm 238$ & $97.9 \pm 0.2$ & $47,075 \pm 330$ & $21,887 \pm 85$ & 0.97 & \\
\hline \multirow{2}{*}{$210^{\circ} \mathrm{C}, 5 \mathrm{~min}$} & $\mathrm{SP}$ & $4.2 \pm 0.1$ & $147,245 \pm 1664$ & $703 \pm 96$ & $146,489 \pm 1699$ & $89.3 \pm 1.0$ & $291,142 \pm 13,393$ & $10,932 \pm 459$ & 0.04 & \multirow{2}{*}{0.14} \\
\hline & LP & $4.0 \pm 0.1$ & $37,970 \pm 638$ & $1391 \pm 531$ & $36,554 \pm 110$ & $99.5 \pm 1.7$ & $51,777 \pm 161$ & $36,133 \pm 325$ & 0.74 & \\
\hline
\end{tabular}




\subsection{Solubilization of Sugars after the Application of the Hydrothermal Treatments}

\subsubsection{Water-Soluble Sugars}

Figure 1 shows the concentrations of water-soluble sugars at $25{ }^{\circ} \mathrm{C}$, which were quantified and expressed as mg D-glucose equivalent per kilogram of RE, from the RE, SP, and LP after each hydrothermal treatment. In all cases, sugar concentrations were increased after hydrothermal treatments compared to the untreated RE (Figure 1). RE contained a low amount of water-soluble sugars, which could be because during the processing of the raspberries to obtain the raspberry concentrate, most of the sugars were displaced to this concentrate. The application of the different hydrothermal treatments increased the concentration of the water-soluble sugars by several times compared to the untreated RE because the sugars were mainly displaced to the LPs (Figure 1). This increase in sugars could be because hydrothermal treatments favor the solubilization and alteration of the cell wall material contained in RE to lower polymerized oligosaccharides and monosaccharides such as water-soluble sugars [26]. The maximum concentration of water-soluble sugars was achieved in the $\mathrm{LP}$ after the hydrothermal treatment at $120^{\circ} \mathrm{C}$, where it obtained a value around 15 times higher than that of the untreated RE, i.e., $21,571 \pm 93 \mathrm{mg} / \mathrm{kg}$ RE and $1378 \pm 10 \mathrm{mg} / \mathrm{kg}$ RE, respectively (Figure 1). The increase in the concentration with respect to the untreated RE may be due to the solubilization of sugars from lignocellulosic matter during the hydrothermal treatments $[25,39,40]$. However, for temperatures above $120^{\circ} \mathrm{C}$, it is likely that sugars were degraded into other compounds such as hydroxymethylfurfural (HMF), which could explain the decrease in the concentration with respect to the maximum achieved at $120^{\circ} \mathrm{C}[21,26]$. The decrease in the concentration of soluble sugar with the increase in the temperature of the hydrothermal treatments was previously reported for strawberry extrudate by Rodríguez-Gutiérrez et al. [21], who reported a decrease from 50 to $18 \mathrm{~g} / \mathrm{kg}$ of strawberry extrudate when the treatment temperature increased from $150^{\circ} \mathrm{C}$ to $200^{\circ} \mathrm{C}$.

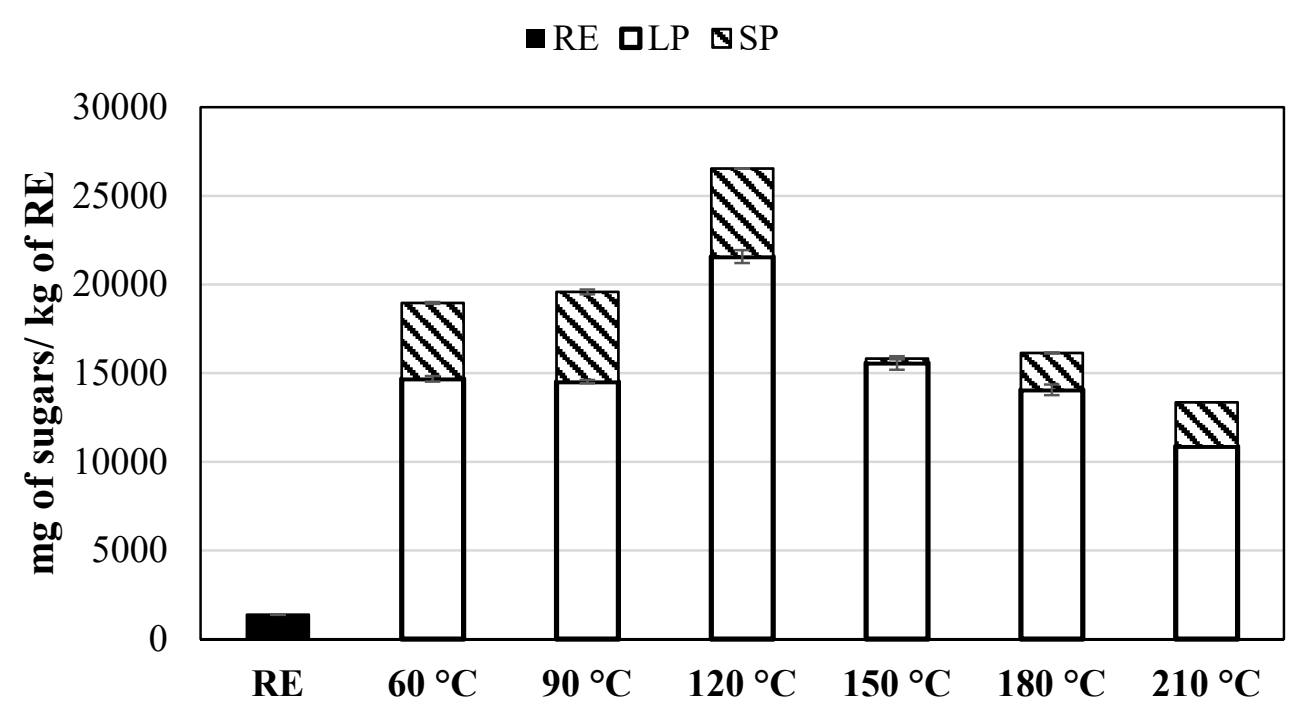

Figure 1. Milligrams of sugars (D-glucose equivalents) per kilogram of extrudate for untreated raspberry extrudate $(\mathrm{RE})$ and different fractions obtained after the hydrothermal treatments.

\subsubsection{Water-Soluble Acid Sugars}

Figure 2 shows the concentration of water-soluble acid sugars at $25^{\circ} \mathrm{C}$, which are expressed as mg of galacturonic acid equivalents per kilogram of RE for the RE, the SP, and the LP after each hydrothermal treatment. After the different hydrothermal treatments, the concentration of acid sugars increased with respect to the untreated RE in all cases, except at $60^{\circ} \mathrm{C}$ (Figure 2). Generally, the concentration of acid sugars increased as temperatures increased, except for the hydrothermal treatments at 150 and $180^{\circ} \mathrm{C}$. The highest concentration of water-soluble acid sugars was obtained 
with the hydrothermal treatment at $210{ }^{\circ} \mathrm{C}$, with a concentration in the LP that was more than twice the acid sugars in the untreated RE, i.e., $4620 \pm 91 \mathrm{mg} / \mathrm{L}$ and $2084 \pm 51 \mathrm{mg} / \mathrm{L}$, respectively. It has been reported that an increase in acid sugars is a consequence of the solubilization of higher molecules such as hemicelluloses and pectins [21,41]. Besides, with regard to the LP, there was an inflection point at $120^{\circ} \mathrm{C}$ (Figure 2). As described for soluble sugars, the concentration of acid sugars in LP was higher than that found in the SP after each hydrothermal treatment (Figure 2).

$\square$ RE $\square$ LP $\triangle \mathrm{SP}$

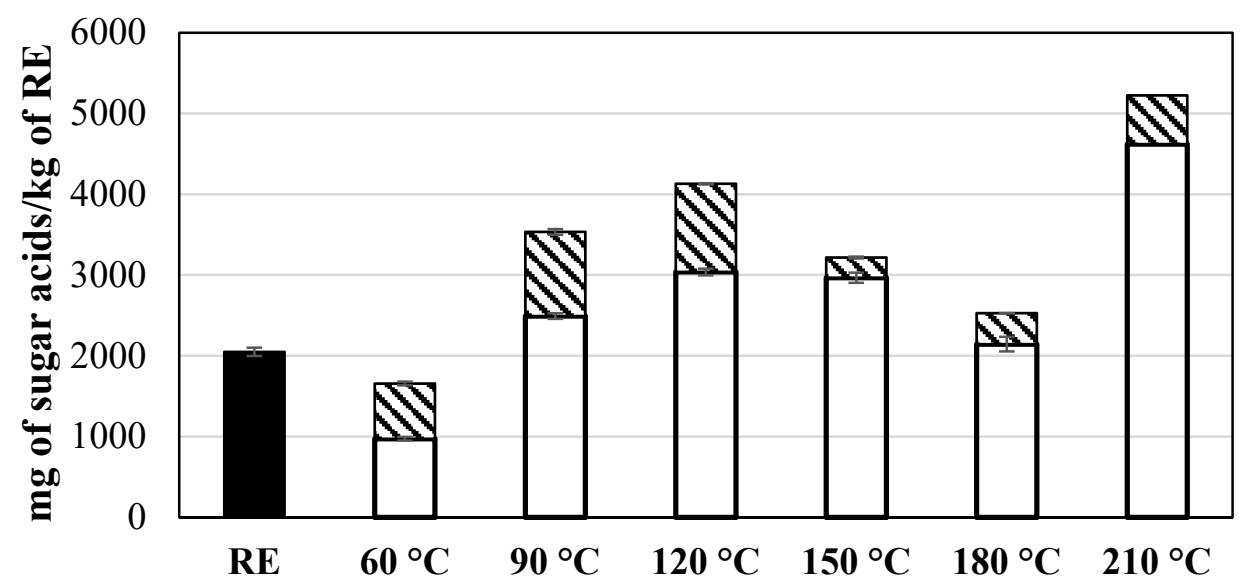

Figure 2. Sugar acids expressed as grams of galacturonic acid per kilogram of extrudate for untreated $\mathrm{RE}$ and different fractions obtained after the hydrothermal treatments.

\subsubsection{Individual Water-Soluble Sugars}

Table 3 shows the glycoside composition of the soluble sugars that comes from the cell wall material and the HMF concentration, which are expressed as milligrams or grams of each individual sugar per kilogram of RE. Untreated RE contained a lower concentration of each individual compound than the thermally treated RE, with the same trend described for water-soluble sugars as shown in Figure 1. In all cases, glucose was the main sugar in the LPs after each hydrothermal treatment, followed by mannose, which was taken as the sum of mannose and mannitol (Table 3). The higher concentration of monosaccharides with respect to the oligosaccharides after the thermal treatments indicates that the treatment conditions favored the hydrolysis of the hemicellulosic and cellulosic structures of the RE.

The application of high temperatures to lignocellulosic substrates has been reported to favor the degradation of sugars into furanic compounds such as the HMF [21,25]. HMF was only found in the LP of hydrothermal treatments performed at temperatures higher than $120^{\circ} \mathrm{C}$ (Table 3), which is in line with the increasing severity of the hydrothermal treatments [42]. The higher concentration of HMF was determined after the hydrothermal treatment carried out at $180^{\circ} \mathrm{C}$, i.e., $6901 \pm 10 \mathrm{mg} / \mathrm{kg}$ RE (Table 3). The formation of HMF may be of interest since it has been found that it can be used to impede the oxidation of edible oils, thus improving the commercial life of sunflower oils by up to four times [21,43]. However, the formation of HMF could also result in some limitations in the subsequent bioprocessing of the treated RE due to its widely reported microbial inhibitory effect [25]. 
Table 3. Glycoside composition (g sugar/kg of raspberry extrudate), total monosaccharides (Total MS) and total oligosaccharides (Total OS) and hydroxymethylfurfural (HMF, $\mathrm{mg} / \mathrm{kg}$ of raspberry extrudate) of untreated raspberry extrudate (RE), solid phase (SP), liquid phase (LP) and de-phenolized liquid phase (DLP). The analyzed sugars are Rhamnose (Rha), Fucose (Fuc), Arabinose (Ara), Xylose (Xyl), Mannose (Man), Galactose (Gal) and Glucose (Glu). n.d. non-detected.

\begin{tabular}{|c|c|c|c|c|c|c|c|c|c|c|c|}
\hline Treatment & Phase & Rha & Fuc & Ara & Xyl & Man & Gal & Glu & Total OS & Total MS & HMF \\
\hline $\mathrm{RE}$ & & $0.07 \pm 0.00$ & n.d & $0.25 \pm 0.00$ & $0.29 \pm 0.00$ & $0.11 \pm 0.01$ & $0.07 \pm 0.00$ & $0.15 \pm 0.00$ & $0.98 \pm 0.02$ & $0.93 \pm 0.01$ & n.d \\
\hline \multirow[t]{2}{*}{$60^{\circ} \mathrm{C}, 60 \mathrm{~min}$} & $\mathrm{SP}$ & $0.17 \pm 0.00$ & n.d & $0.60 \pm 0.05$ & $0.46 \pm 0.01$ & $1.49 \pm 0.16$ & n.d & $4.09 \pm 0.04$ & $3.25 \pm 0.18$ & $6.81 \pm 0.17$ & n.d \\
\hline & LP & $0.07 \pm 0.00$ & n.d & $0.26 \pm 0.01$ & $0.28 \pm 0.01$ & $3.16 \pm 0.20$ & n.d & $10.17 \pm 0.79$ & $8.01 \pm 0.91$ & $13.99 \pm 0.81$ & n.d \\
\hline \multirow[t]{2}{*}{$90^{\circ} \mathrm{C}, 60 \mathrm{~min}$} & $\mathrm{SP}$ & $0.22 \pm 0.03$ & n.d & $0.35 \pm 0.50$ & $0.54 \pm 0.02$ & $1.51 \pm 0.30$ & n.d & $4.24 \pm 0.50$ & $3.53 \pm 1.23$ & $6.85 \pm 0.77$ & n.d \\
\hline & LP & $0.08 \pm 0.00$ & n.d & $0.25 \pm 0.02$ & $0.30 \pm 0.00$ & $3.60 \pm 0.03$ & n.d & $11.70 \pm 0.01$ & $10.60 \pm 0.13$ & $15.98 \pm 0.04$ & n.d \\
\hline \multirow[t]{2}{*}{$120^{\circ} \mathrm{C}, 60 \mathrm{~min}$} & SP & $0.23 \pm 0.02$ & n.d & $0.77 \pm 0.00$ & $0.58 \pm 0.03$ & $1.58 \pm 0.15$ & n.d & $4.56 \pm 0.47$ & $4.19 \pm 0.58$ & $7.77 \pm 0.50$ & n.d \\
\hline & LP & $0.12 \pm 0.00$ & n.d & $0.59 \pm 0.01$ & $0.38 \pm 0.01$ & $3.44 \pm 0.08$ & n.d & $11.30 \pm 0.39$ & $9.89 \pm 0.43$ & $15.91 \pm 0.40$ & $176 \pm 10$ \\
\hline \multirow[t]{2}{*}{$150^{\circ} \mathrm{C}, 60 \mathrm{~min}$} & $\mathrm{SP}$ & $0.01 \pm 0.00$ & n.d & $0.07 \pm 0.00$ & $0.03 \pm 0.00$ & $0.03 \pm 0.00$ & n.d & $0.06 \pm 0.00$ & $0.31 \pm 0.05$ & $0.20 \pm 0.00$ & n.d \\
\hline & LP & $0.09 \pm 0.00$ & n.d & $0.73 \pm 0.00$ & $0.35 \pm 0.00$ & $3.13 \pm 0.08$ & $0.13 \pm 0.00$ & $10.78 \pm 0.44$ & $8.84 \pm 0.46$ & $15.21 \pm 0.45$ & $864 \pm 10$ \\
\hline \multirow[t]{2}{*}{$180^{\circ} \mathrm{C}, 60 \mathrm{~min}$} & SP & $0.10 \pm 0.00$ & n.d & $0.37 \pm 0.02$ & $0.27 \pm 0.03$ & $0.23 \pm 0.04$ & n.d & $0.71 \pm 0.14$ & $0.58 \pm 0.44$ & $1.73 \pm 0.15$ & n.d \\
\hline & LP & $0.09 \pm 0.00$ & n.d & $0.97 \pm 0.01$ & $0.95 \pm 0.01$ & $1.66 \pm 0.01$ & $0.43 \pm 0.01$ & $6.39 \pm 0.07$ & $5.74 \pm 0.16$ & $10.49 \pm 0.07$ & $6901 \pm 10$ \\
\hline \multirow[t]{2}{*}{$210^{\circ} \mathrm{C}, 5 \mathrm{~min}$} & $\mathrm{SP}$ & $0.12 \pm 0.01$ & n.d & $0.49 \pm 0.03$ & $0.35 \pm 0.02$ & $0.52 \pm 0.03$ & n.d & $1.23 \pm 0.02$ & $1.35 \pm 0.20$ & $2.75 \pm 0.05$ & n.d \\
\hline & LP & $0.07 \pm 0.00$ & n.d & $0.73 \pm 0.02$ & $0.43 \pm 0.02$ & $1.46 \pm 0.05$ & $0.17 \pm 0.01$ & $4.88 \pm 0.15$ & $5.06 \pm 0.61$ & $7.74 \pm 0.16$ & $518 \pm 10$ \\
\hline
\end{tabular}




\subsection{Solubilization of Phenols after the Application of Hydrothermal Treatments}

Figure 3 shows the influence of temperature on the phenols extracted in RE, as well as in the different LP and SP obtained after each hydrothermal treatment. As can be seen, two different trends were detected: at temperatures below $120^{\circ} \mathrm{C}$, there is a slight decrease in the concentration of phenolic compounds at increasing temperatures, which may be due to the degradation of thermosensitive compounds [44]. At temperatures above $120^{\circ} \mathrm{C}$, the structure of the RE began to degrade, releasing the phenolic compounds retained in the lignocellulosic structures. The maximum concentration of phenols was achieved after the steam explosion treatment at $210{ }^{\circ} \mathrm{C}$, which was around twice that determined for the untreated RE, i.e., $5169 \pm 33 \mathrm{mg}$ of gallic acid $/ \mathrm{kg}$ RE and $2497 \pm 115 \mathrm{mg}$ of gallic acid $/ \mathrm{kg} \mathrm{RE}$, respectively (Figure 3). The high concentration of phenols found after the steam explosion treatment could be a consequence of the high severity of the treatment compared to conventional hydrothermal treatments. Steam explosion treatments affect most of the hemicelluloses and celluloses and, even, part of the lignin thanks to the fast pressure reduction, whereas conventional hydrothermal treatments only degrade hemicellulose, and partially degrade the cellulose $[45,46]$. On the other hand, it was observed that the concentration of phenols in most SPs was higher than those contained in LPs after the hydrothermal treatments. A positive trend in the solubilization of phenols in the LP was observed with the increase in the temperature (Figure 3), similar to that reported in other studies on the treatment of strawberry extrudate [21]. Despite the solubilization of the phenols, the SP had a higher concentration of phenols than the LP after all of the hydrothermal treatments, except for $210^{\circ} \mathrm{C}$, which could be a consequence of the high phenolic content of the achenes that remained in the SP [47].

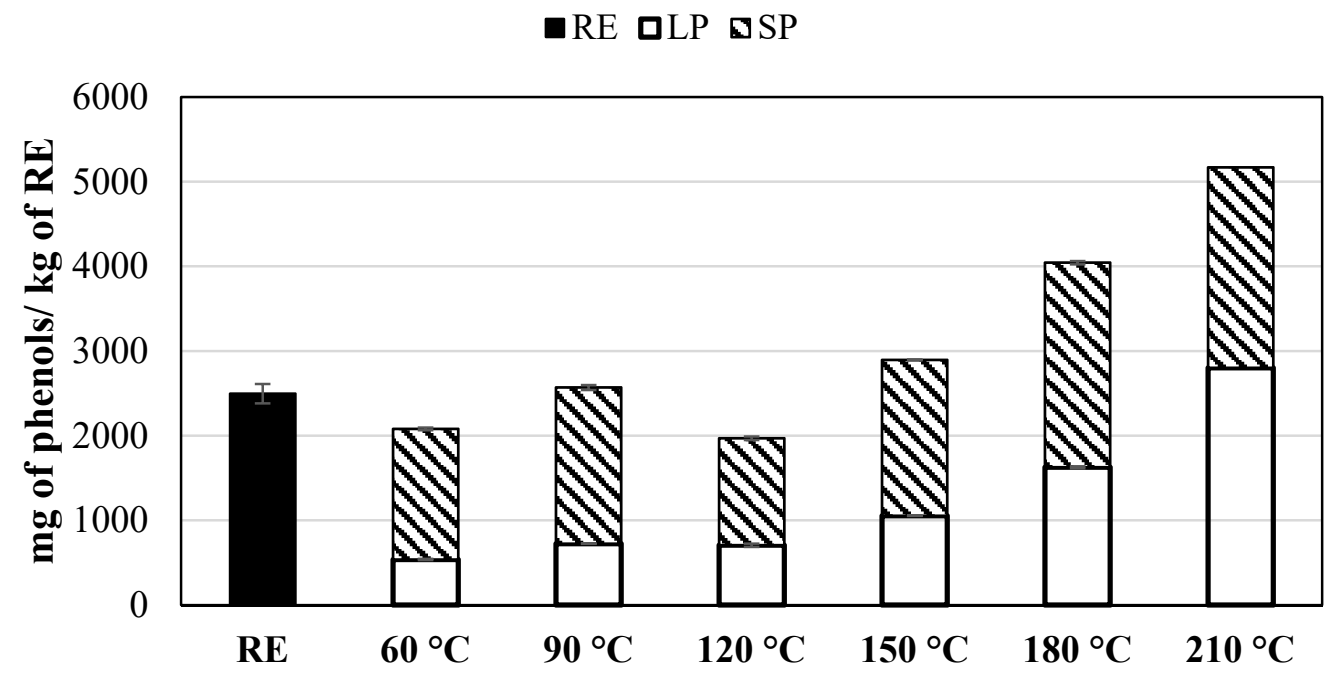

Figure 3. Phenols expressed as milligrams of gallic acid equivalents per kilogram of extrudate for untreated RE and different fractions obtained after the hydrothermal treatments.

Table 4 shows the concentrations of individual anthocyanins and phenolic compounds in the LP after each hydrothermal treatment. As can be seen, the total content of anthocyanins, which corresponds to the sum of each individual anthocyanin, was 26.79 and $19.26 \mathrm{mg} / \mathrm{kg} \mathrm{RE}$, after treatments carried out at $60^{\circ} \mathrm{C}$ and $90^{\circ} \mathrm{C}$, respectively. However, total anthocyanins were not found at temperatures above $90^{\circ} \mathrm{C}$. The total content of anthocyanins obtained after the application of hydrothermal treatments were very low compared to those obtained for fresh red raspberry fruit, $200-1000 \mathrm{mg} / \mathrm{kg}$ fresh fruit [2]. As shown in other studies, anthocyanins are thermosensitive compounds, and therefore, they are susceptible to thermal degradation [48]. This explains the absence of these compounds at temperatures equal to and higher than $120^{\circ} \mathrm{C}$. Otherwise, hydrothermal treatments at $120,150,180$, and $210{ }^{\circ} \mathrm{C}$ resulted in the release of ellagic acid and ellagic acid derivatives (Table 4). The quantified free ellagic acid content was similar to that reported in other studies for fresh red raspberry fruit, i.e., $1-10 \mathrm{mg} / \mathrm{kg}$ 
fresh fruit $[7,8,49,50]$. However, a markedly higher concentration of ellagic acid derivative, probably an oxidized derivative, was determined after these hydrothermal treatments, with the concentration increasing with increasing treatment temperatures (Table 4).

Table 4. Concentration of individual phenolic compounds obtained after each hydrothermal treatment.

\begin{tabular}{|c|c|c|c|c|c|c|}
\hline Concentration $(\mathrm{mg} / \mathrm{kg})$ & $\begin{array}{c}60{ }^{\circ} \mathrm{C} \\
60 \mathrm{~min}\end{array}$ & $\begin{array}{l}90^{\circ} \mathrm{C} \\
60 \mathrm{~min}\end{array}$ & $\begin{array}{l}120^{\circ} \mathrm{C}, \\
60 \mathrm{~min}\end{array}$ & $\begin{array}{l}150{ }^{\circ} \mathrm{C} \\
60 \mathrm{~min}\end{array}$ & $\begin{array}{l}180{ }^{\circ} \mathrm{C}, \\
60 \mathrm{~min}\end{array}$ & $\begin{array}{c}210{ }^{\circ} \mathrm{C} \\
5 \mathrm{~min}\end{array}$ \\
\hline Cyanidin-3-glucoside & 20.87 & 17.17 & - & - & - & - \\
\hline Other anthocyanins & 1.53 & 2.09 & - & - & - & - \\
\hline Quercetin-3-glucoside (350 nm) & 4.39 & - & - & - & - & - \\
\hline Ellagic Acid Free $(350 \mathrm{~nm})$ & - & - & 1.56 & 0.78 & 0.71 & 0.00 \\
\hline $\begin{array}{l}\text { Ellagic Acid derivative (RT: } \\
16.7 \mathrm{~min} \text { ) }\end{array}$ & - & - & 27.52 & 29.87 & 77.20 & 85.98 \\
\hline
\end{tabular}

\subsection{Antioxidant Determination}

The antioxidant power of each LP obtained after hydrothermal treatments was determined by the antiradical activity and the power to reduce free radicals. All values for DPPH EC 50 in the LP obtained after each hydrothermal treatment were higher than the value of $\mathrm{RE}$, with the lowest value for the hydrothermal treatment at $210{ }^{\circ} \mathrm{C}$ (Figure 4A). This indicates a loss of antioxidant capacity in the treated fractions with respect to the untreated RE. This could be a consequence of the degradation of highly antioxidant thermosensitive compounds, such as the anthocyanins during the hydrothermal treatments [48]. Similarly, most of the fractions showed a lower reducing capacity, expressed as Trolox equivalents in $\mathrm{mg} / \mathrm{mL}$, than the untreated RE (Figure 4B). Only the liquid fraction at $90{ }^{\circ} \mathrm{C}$ showed higher reducing activity than the RE, i.e., $0.167 \pm 0.001$ and $0.148 \pm 0.004 \mathrm{mg} / \mathrm{mL}$, respectively.

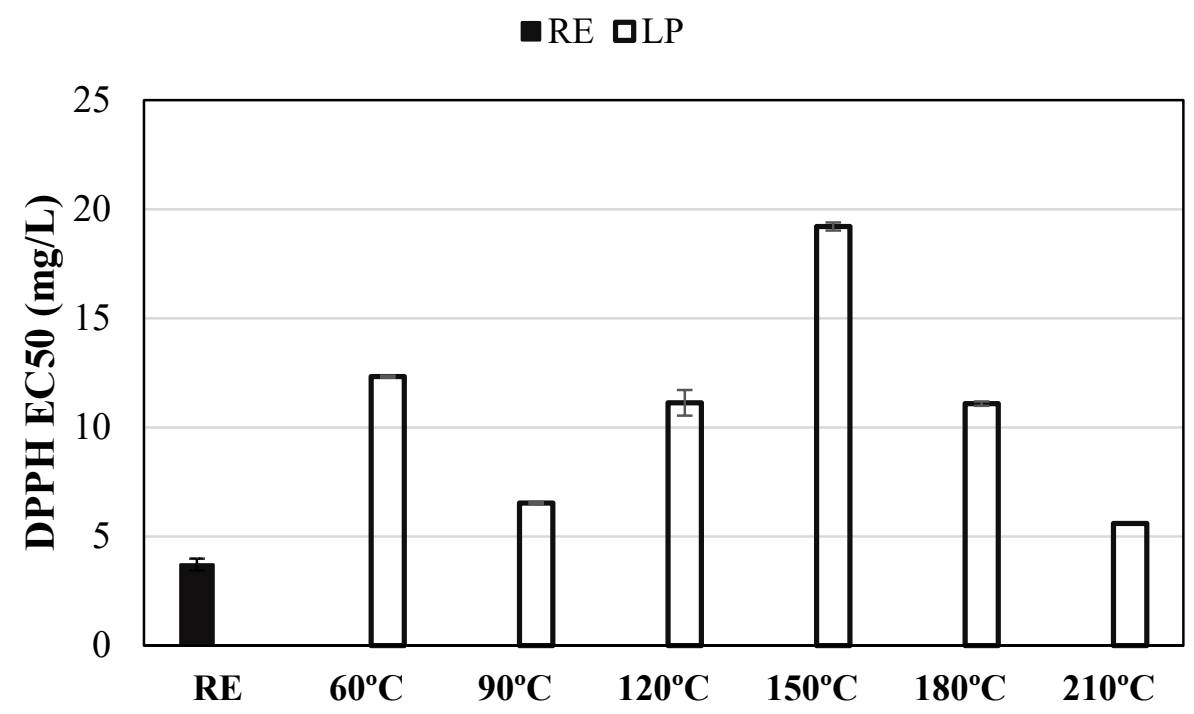

(A)

Figure 4. Cont. 


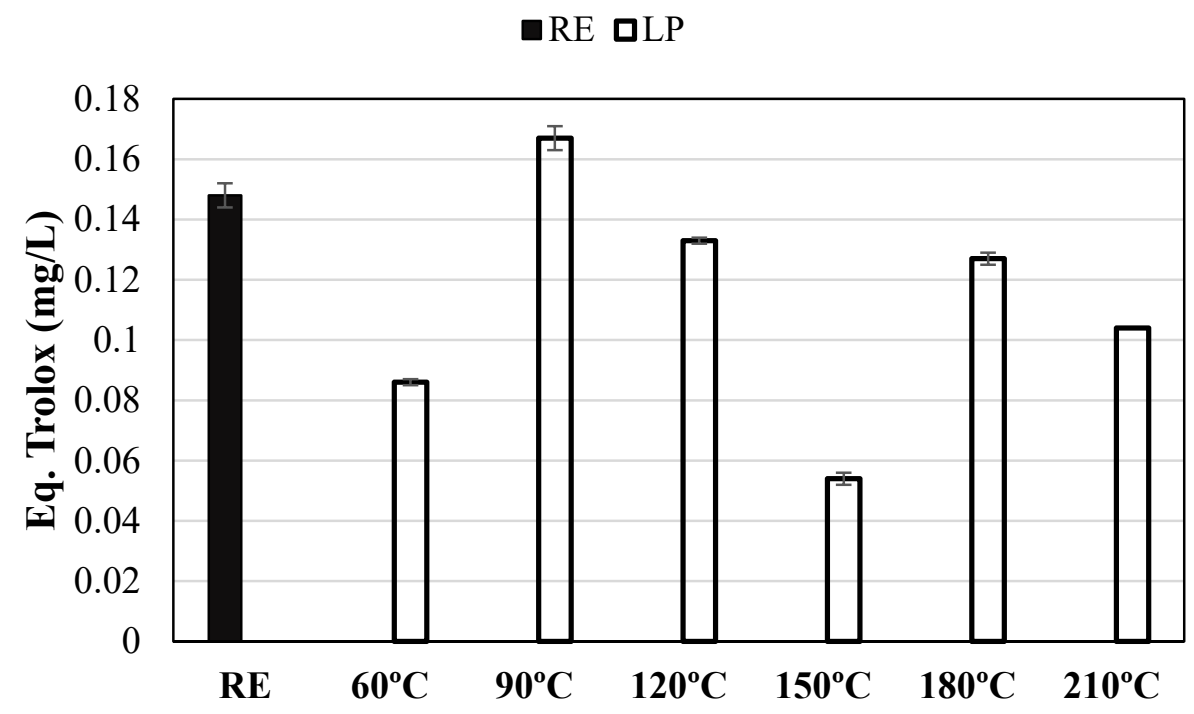

(B)

Figure 4. Antioxidant capacity determined by antiradical activity (DPPH) (A) and reducing power (B) methods of extrudate for untreated RE and each LP obtained after hydrothermal pre-treatments.

\subsection{Achenes}

The hydrothermal treatments in the studied range did not affect the form and size of the achenes, although a darkening of the achenes was detected at temperatures higher than $120^{\circ} \mathrm{C}$ (Figure 5). Achenes from hydrothermal treatment at $180{ }^{\circ} \mathrm{C}$ were the darkest, which is probably related to the high severity of the treatment and the high concentration of HMF generated at this temperature (Table 3). Table 5 shows the percentages of achenes in dry weight that were quantified in untreated RE and the different SPs, obtained after each hydrothermal treatment. The percentage of achenes in RE was s $89 \%$, while the percentage of achenes after each hydrothermal treatment was more than $92 \%$. The treatment at $180{ }^{\circ} \mathrm{C}$ had the highest percentage, with a value of $97 \%$ (Table 5). These results show that hydrothermal treatments are not severe enough to break the achenes despite their high presence in the RE. Therefore, further research could consider the implementation of another type of treatments to break the achenes to facilitate the release of the high-added value compounds that are present in the achenes [15].

Table 5. Quantification of achenes present in untreated RE and in the different SPs obtained after each hydrothermal treatment (percentage of achenes in dry weight).

\begin{tabular}{cccccccc}
\hline Treatment & RE & $\begin{array}{c}\mathbf{6 0}{ }^{\circ} \mathbf{C}, \\
\mathbf{6 0} \mathbf{~ m i n}\end{array}$ & $\begin{array}{c}\mathbf{9 0}{ }^{\circ} \mathbf{C}, \\
\mathbf{6 0} \mathbf{~ m i n}\end{array}$ & $\begin{array}{c}\mathbf{1 2 0}{ }^{\circ} \mathbf{C}, \\
\mathbf{6 0} \mathbf{~ m i n}\end{array}$ & $\begin{array}{c}\mathbf{1 5 0}{ }^{\circ} \mathbf{C}, \\
\mathbf{6 0} \mathbf{~ m i n}\end{array}$ & $\begin{array}{c}\mathbf{1 8 0}{ }^{\circ} \mathbf{C}, \\
\mathbf{6 0} \mathbf{~ m i n}\end{array}$ & $\begin{array}{c}\mathbf{2 1 0}{ }^{\circ} \mathbf{C}, \\
\mathbf{5} \mathbf{~ m i n}\end{array}$ \\
\hline $\begin{array}{c}\text { Achenes } \\
(\% \text { dry weight })\end{array}$ & $89.5 \pm 1.4$ & $94.1 \pm 0.6$ & $95.0 \pm 1.2$ & $94.8 \pm 1.0$ & $94.5 \pm 1.1$ & $97.2 \pm 0.8$ & $92.3 \pm 1.0$ \\
\hline
\end{tabular}




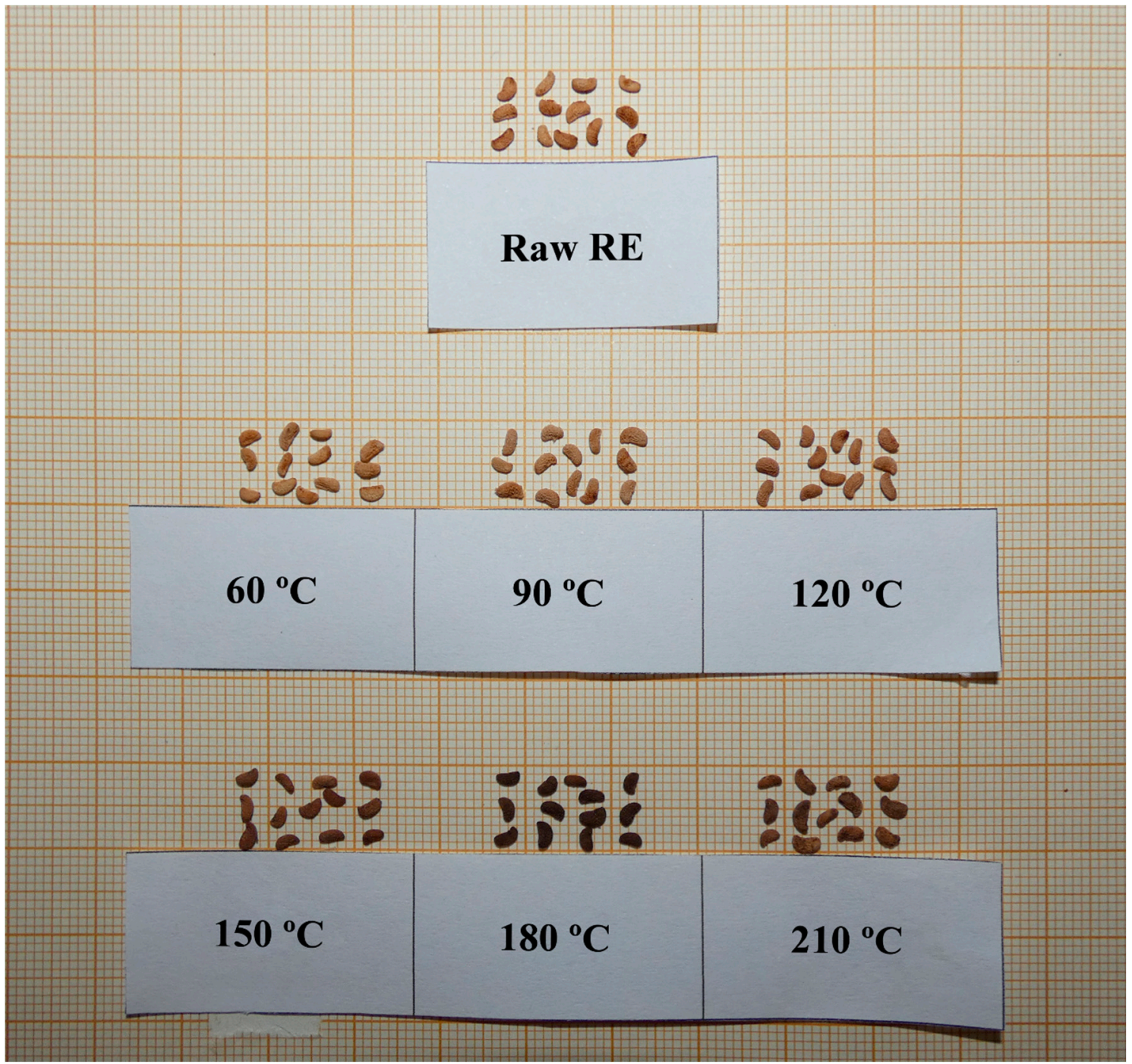

Figure 5. Achenes present in the untreated RE and in the different SPs obtained after each hydrothermal treatment (a graph paper with a $1 \mathrm{~mm}$ scale has been used as a photographic background).

\section{Conclusions}

The solubilization of phenols and sugars, and their concentration and composition, from raspberry extrudate is highly dependent on the operational conditions of the applied hydrothermal treatments. Higher temperatures usually result in higher solubilization, as well as better separation of the treated raspberries in the solid and liquid phases. The maximum concentration of water-soluble sugars was achieved in the LP after the hydrothermal treatment at $120^{\circ} \mathrm{C}$, where it was around 15 times higher than that of the untreated RE. Otherwise, the hydrothermal treatment at $210^{\circ} \mathrm{C}$ for $5 \mathrm{~min}$ and the subsequent decompression resulted in the highest concentration of water-soluble acid sugars. The solubilization of phenolic compounds showed a positive trend with respect to the hydrothermal treatment temperature, reaching a high value of $5169 \pm 33 \mathrm{mg}$ of gallic acid $/ \mathrm{kg}$ RE after the hydrothermal treatment at $210^{\circ} \mathrm{C}$. However, an increase in the hydrothermal treatment temperature above $90{ }^{\circ} \mathrm{C}$ resulted in the decomposition of thermosensitive compounds such as anthocyanins. The hydrothermal treatment at $210{ }^{\circ} \mathrm{C}$ was considered as optimal because of its high solubilization capacity, with the additional advantage of lower generation of undesirable HMF compared to the other assessed conventional hydrothermal treatments. 
Author Contributions: Conceptualization, G.R.-G. and F.G.F.; methodology, Á.T.-R. and P.M.-A.; formal analysis, G.R.-G. and A.S.; resources, G.R.-G. and R.B.; writing-original draft preparation, J.C.-C. and Á.T.-R.; writing-review and editing, D.V.-G., A.S. and F.G.F.; supervision, F.G.F.; funding acquisition, R.B. and F.G.F. All authors have read and agreed to the published version of the manuscript.

Funding: This research was funded by the Spanish Ministry of Economy and Competitiveness by Project CTM2017-83870. R.A. Serrano acknowledges the support of the University of Queensland through the project UQECR1945969.

Conflicts of Interest: The authors declare no conflict of interest.

\section{References}

1. FAO. FAOSTAT: Food and Agriculture Organization of the United Nations. Available online: http://www.fao. org/faostat (accessed on 21 April 2020).

2. Bobinaite, R.; Viškelis, P.; Venskutonis, P.R. Chemical composition of raspberry (Rubus spp.) cultivars. In Nutritional Composition of Fruit Cultivars; Elsevier: Amsterdam, The Netherlands, 2016; pp. 713-731.

3. Martinsen, B.K.; Aaby, K.; Skrede, G. Effect of temperature on stability of anthocyanins, ascorbic acid and color in strawberry and raspberry jams. Food Chem. 2020, 316. [CrossRef] [PubMed]

4. Qin, Y.; Wang, L.; Liu, Y.; Zhang, Q.; Li, Y.; Wu, Z. Release of phenolics compounds from Rubus idaeus L. dried fruits and seeds during simulated in vitro digestion and their bio-activities. J. Funct. Foods 2018, 46, 57-65. [CrossRef]

5. Määttä-Riihinen, K.R.; Kamal-Eldin, A.; Törrönen, A.R. Identification and quantification of phenolic compounds in berries of Fragaria and Rubus species (family Rosaceae). J. Agric. Food Chem. 2004, 52, 6178-6187. [CrossRef] [PubMed]

6. Melo, M.J.; Moncada, M.C.; Pina, F. On the red colour of raspberry (Rubus idaeus). Tetrahedron Lett. 2000, 41, 1987-1991. [CrossRef]

7. Rao, A.V.; Snyder, D.M. Raspberries and human health: A review. J. Agric. Food Chem. 2010, 58, 3871-3883. [CrossRef]

8. Salinas-Moreno, Y.; Almaguer-Vargas, G.; Peña-Varela, G.; Ríos-Sánchez, R. Ácido elágico y perfil de antocianinas en frutos de frambuesa (Rubus idaeus L.) con diferente grado de maduración. Rev. Chapingo Ser. Hortic. 2009, 15, 97-101. [CrossRef]

9. Tasaki, M.; Umemura, T.; Maeda, M.; Ishii, Y.; Okamura, T.; Inoue, T.; Kuroiwa, Y.; Hirose, M.; Nishikawa, A. Safety assessment of ellagic acid, a food additive, in a subchronic toxicity study using F344 rats. Food Chem. Toxicol. 2008, 46, 1119-1124. [CrossRef]

10. Mishra, S.; Singh, P.K.; Dash, S.; Pattnaik, R. Microbial pretreatment of lignocellulosic biomass for enhanced biomethanation and waste management. 3 Biotech 2018, 8, 458. [CrossRef]

11. Nieto-Calvache, J.E.; de Escalada Pla, M.; Gerschenson, L.N. Dietary fibre concentrates produced from papaya by-products for agroindustrial waste valorisation. Int. J. Food Sci. Technol. 2019, 54, 1074-1080. [CrossRef]

12. Gagneten, M.; Corfield, R.; Mattson, M.G.; Sozzi, A.; Leiva, G.; Salvatori, D.; Schebor, C. Spray-dried powders from berries extracts obtained upon several processing steps to improve the bioactive components content. Powder Technol. 2019, 342, 1008-1015. [CrossRef]

13. Aaby, K.; Skrede, G.; Wrolstad, R.E. Phenolic composition and antioxidant activities in flesh and achenes of strawberries (Fragaria ananassa). J. Agric. Food Chem. 2005, 53, 4032-4040. [CrossRef] [PubMed]

14. Ariza, M.T.; Reboredo-Rodríguez, P.; Mazzoni, L.; Forbes-Hernández, T.Y.; Giampieri, F.; Afrin, S.; Gasparrini, M.; Soria, C.; Martínez-Ferri, E.; Battino, M. Strawberry achenes are an important source of bioactive compounds for human health. Int. J. Mol. Sci. 2016, 17, 1103. [CrossRef]

15. Samoraj, M.; Tuhy, Ł.; Chojnacka, K. Valorization of Biomass into Micronutrient Fertilizers. Waste Biomass Valoriz. 2019, 10, 925-931. [CrossRef]

16. Balasundram, N.; Sundram, K.; Samman, S. Phenolic compounds in plants and agri-industrial by-products: Antioxidant activity, occurrence, and potential uses. Food Chem. 2006, 99, 191-203. [CrossRef]

17. Hornedo-Ortega, R.; Álvarez-Fernández, M.A.; Cerezo, A.B.; Garcia-Garcia, I.; Troncoso, A.M.; Garcia-Parrilla, M.C. Influence of fermentation process on the anthocyanin composition of wine and vinegar elaborated from strawberry. J. Food Sci. 2017, 82, 364-372. [CrossRef] 
18. Strazzera, G.; Battista, F.; Garcia, N.H.; Frison, N.; Bolzonella, D. Volatile fatty acids production from food wastes for biorefinery platforms: A review. J. Environ. Manag. 2018, 226, 278-288. [CrossRef]

19. Rodriguez-Perez, S.; Serrano, A.; Pantión, A.A.; Alonso-Fariñas, B. Challenges of scaling-up PHA production from waste streams: A review. J. Environ. Manag. 2018, 205, 215-230. [CrossRef]

20. Chamorro, R.A.M.; Mamani, E.C. Importancia de la fibra dietética, sus propiedades funcionales en la alimentación humana y en la industria alimentaria. Revista de investigación en ciencia y tecnología de alimentos 2010, 1, 4-17.

21. Rodríguez-Gutiérrez, G.; Cardoso, J.C.; Rubio-Senent, F.; Serrano, A.; Borja, R.; Fernández-Bolaños, J.; Fermoso, F.G. Thermally-treated strawberry extrudate: A rich source of antioxidant phenols and sugars. Innov. Food Sci. Emerg. Technol. 2019, 51, 186-193. [CrossRef]

22. Rubio-Senent, F.t.; Rodríguez-Gutíerrez, G.; Lama-Muñoz, A.; Fernández-Bolaños, J. New phenolic compounds hydrothermally extracted from the olive oil byproduct alperujo and their antioxidative activities. J. Agric. Food Chem. 2012, 60, 1175-1186. [CrossRef]

23. Fuentes-Alventosa, J.; Jaramillo-Carmona, S.; Rodríguez-Gutiérrez, G.; Guillén-Bejarano, R.; Jiménez-Araujo, A.; Fernández-Bolaños, J.; Rodríguez-Arcos, R. Preparation of bioactive extracts from asparagus by-product. Food Bioprod. Process. 2013, 91, 74-82. [CrossRef]

24. Jain, S.; Jain, S.; Wolf, I.T.; Lee, J.; Tong, Y.W. A comprehensive review on operating parameters and different pretreatment methodologies for anaerobic digestion of municipal solid waste. Renew. Sustain. Energy Rev. 2015, 52, 142-154. [CrossRef]

25. Hendriks, A.; Zeeman, G. Pretreatments to enhance the digestibility of lignocellulosie biomass. Bioresour. Technol. 2009, 100, 10-18. [CrossRef] [PubMed]

26. Fernández-Bolaños, J.; Rodríguez, G.; Gómez, E.; Guillén, R.; Jiménez, A.; Heredia, A.; Rodríguez, R. Total recovery of the waste of two-phase olive oil processing: Isolation of added-value compounds. J. Agric. Food Chem. 2004, 52, 5849-5855. [CrossRef]

27. Fernández-Bolaños, J.; Rodríguez-Gutiérrez, G.; Lama-Muñoz, A.; Fernández-Bolaños, J.M.; Maya-Castilla, I.; Rubio-Senent, F.; Marset Castro, A. Method for Obtaining Hydroxytyrosol Extract, Mixture of Hydroxytyrosol and 3,4-Dihydroxyphenylglycol Extract, and Hydroxytyrosyl Acetate Extract from By-Products of the Olive Tree and the Purification of Thereof. International Patent No. WO 2013/007850A1, 17 January 2013.

28. Thompson, W.; Leege, P.; Millner, P.; Watson, M. Test Methods for the Examination of Composting and Compost; The United States Composting Council Research and Education Foundation. The United States Department of Agriculture: Washington, WA, USA, 2001.

29. APHA. Standard Methods for Examination of Water and Wastewater, 23rd ed.; American Public Health Association, American Water Works Association, and Water Environment Federation: Washington, DC, USA, 2017.

30. Mokrash, L. Determination of glucose by the anthrone method. J. Biol. Chem. 1954, 208, 55-59.

31. Blumenkrantz, N.; Asboe-Hansen, G. An automated quantitative assay for uronic acids. Biochem. Med. 1974, 11, 60-66. [CrossRef]

32. Lama-Muñoz, A.; Rodríguez-Gutiérrez, G.; Rubio-Senent, F.; Fernández-Bolaños, J. Production, characterization and isolation of neutral and pectic oligosaccharides with low molecular weights from olive by-products thermally treated. Food Hydrocoll. 2012, 28, 92-104. [CrossRef]

33. Singleton, V.L.; Rossi, J.A. Colorimetry of total phenolics with phosphomolybdic-phosphotungstic acid reagents. Am. J. Enol. Vitic. 1965, 16, 144-158.

34. Gil, M.I.; Holcroft, D.M.; Kader, A.A. Changes in strawberry anthocyanins and other polyphenols in response to carbon dioxide treatments. J. Agric. Food Chem. 1997, 45, 1662-1667. [CrossRef]

35. Pérez, A.; García-Rodríguez, R.; Sanz, C.; Refoyo, A. A10-48-3 and A7-32-10, two strawberry selections with well-balanced nutritional and organoleptic quality. In Proceedings of the VIII International Strawberry Symposium 1156, Québec City, QC, Canada, 13-17 August 2016; pp. 363-370.

36. Rodríguez, G.; Rodríguez, R.; Fernández-Bolaños, J.; Guillén, R.; Jiménez, A. Antioxidant activity of effluents during the purification of hydroxytyrosol and 3,4-dihydroxyphenyl glycol from olive oil waste. Eur. Food Res. Technol. 2007, 224, 733-741. [CrossRef]

37. Serrano, A.; Fermoso, F.G.; Rodríguez-Gutierrez, G.; Fernandez-Bolaños, J.; Borja, R. Biomethanization of olive mill solid waste after phenols recovery through low-temperature thermal pre-treatment. Waste Manag. 2017, 61, 229-235. [CrossRef] 
38. Trujillo-Reyes, Á.; Cubero-Cardoso, J.; Rodríguez-Gutiérrez, G.; García-Martín, J.F.; Rodríguez-Galán, M.; Borja, R.; Serrano, A.; Fermoso, F.G. Extraction of phenolic compounds and production of biomethane from strawberry and raspberry extrudates. Biochem. Eng. J. 2019, 147, 11-19. [CrossRef]

39. Ahmad, F.; Silva, E.L.; Varesche, M.B.A. Hydrothermal processing of biomass for anaerobic digestion-a review. Renew. Sustain. Energy Rev. 2018, 98, 108-124. [CrossRef]

40. Song, X.; Wachemo, A.C.; Zhang, L.; Bai, T.; Li, X.; Zuo, X.; Yuan, H. Effect of hydrothermal pretreatment severity on the pretreatment characteristics and anaerobic digestion performance of corn stover. Bioresour. Technol. 2019, 289, 121646. [CrossRef] [PubMed]

41. Jönsson, L.J.; Martín, C. Pretreatment of lignocellulose: Formation of inhibitory by-products and strategies for minimizing their effects. Bioresour. Technol. 2016, 199, 103-112. [CrossRef]

42. Batista, G.; Souza, R.B.; Pratto, B.; dos Santos-Rocha, M.S.; Cruz, A.J. Effect of severity factor on the hydrothermal pretreatment of sugarcane straw. Bioresour. Technol. 2019, 275, 321-327. [CrossRef]

43. Mrabet, A.; Jiménez-Araujo, A.; Fernández-Bolaños, J.; Rubio-Senent, F.; Lama-Muñoz, A.; Sindic, M.; Rodríguez-Gutiérrez, G. Antioxidant phenolic extracts obtained from secondary Tunisian date varieties (Phoenix dactylifera L.) by hydrothermal treatments. Food Chem. 2016, 196, 917-924. [CrossRef]

44. Struck, S.; Plaza, M.; Turner, C.; Rohm, H. Berry pomace-a review of processing and chemical analysis of its polyphenols. Int. J. Food Sci. Technol. 2016, 51, 1305-1318. [CrossRef]

45. Rodríuez-Gutiérrez, G.; Lama-Muñoz, A.; Rubio-Senent, F.; Fernández-Bolaños, J.; Ruiz-Méndez, M.V. New Olive-Pomace Oil Improved by Hydrothermal Pre-Treatments; INTECH Open Access Publisher: London, UK, 2012.

46. Serrano, A.; Fermoso, F.G.; Alonso-Fariñas, B.; Rodríguez-Gutiérrez, G.; López, S.; Fernandez-Bolaños, J.; Borja, R. Long-term evaluation of mesophilic semi-continuous anaerobic digestion of olive mill solid waste pretreated with steam-explosion. Energies 2019, 12, 2222. [CrossRef]

47. Siles, J.A.; Serrano, A.; Martín, A.; Martín, M.A. Biomethanization of waste derived from strawberry processing: Advantages of pretreatment. J. Clean. Prod. 2013, 42, 190-197. [CrossRef]

48. Oszmiański, J.; Nowicka, P.; Teleszko, M.; Wojdyło, A.; Cebulak, T.; Oklejewicz, K. Analysis of phenolic compounds and antioxidant activity in wild blackberry fruits. Int. J. Mol. Sci. 2015, 16, 14540-14553. [CrossRef] [PubMed]

49. Anttonen, M.J.; Karjalainen, R.O. Environmental and genetic variation of phenolic compounds in red raspberry. J. Food Compos. Anal. 2005, 18, 759-769. [CrossRef]

50. Zafrilla, P.; Ferreres, F.; Tomás-Barberán, F.A. Effect of processing and storage on the antioxidant ellagic acid derivatives and flavonoids of red raspberry (Rubus idaeus) jams. J. Agric. Food Chem. 2001, 49, 3651-3655. [CrossRef] [PubMed]

(C) 2020 by the authors. Licensee MDPI, Basel, Switzerland. This article is an open access article distributed under the terms and conditions of the Creative Commons Attribution (CC BY) license (http://creativecommons.org/licenses/by/4.0/). 